\title{
ARAŞTIRMA / RESEARCH \\ Comparison of the ProSeal laryngeal mask airway and endotracheal tube in septorhinoplasty surgery
}

Septorinoplasti operasyonlarında ProSeal laryngeal maske ve entübasyon tüpünün karşılaştırılması

Dilek Yeniay 1 , Bahanur Çekiç

${ }^{1}$ Giresun Üniversitesi Kadın Doğum ve Çocuk Hastalıkları Eğitim Araştırma Hastanesi, Anesteziyoloji ve Reanimasyon Bölümü, Giresun,Turkey

${ }^{2}$ Karadeniz Teknik Üniversitesi Tip Fakültesi, Anesteziyoloji ve Reanimasyon Anabilim Dalı, Trabzon, Turkey

CukurovaMedicalJournal 2021;46(4):1468-1477

\section{Abstract}

Purpose: The aim of this study is to use ProSeal laryngeal mask airway (PLMA) and endotracheal tube (ETT) in elective septorhinoplasty operation and to compare the hemodynamic differences and postoperative complications during the application.

Materials and Methods: In the prospective planned study, ASA I-II and 60 patients aged 18-35 were randomly allocated into two groups $(\mathrm{n}=30, \mathrm{n}=30)$. After the standard anesthesia technique, Group E was placed ETT, Group P PLMA. Patients' demographic characteristics, number of attempts for correct insertion, hemodynamic changes, postoperative nausea, vomiting, sore throat, hoarseness, dysphagia and surgical satisfaction evaluated. Results: Heart rate was higher in Group E than in Group $\mathrm{P}$ at the $1 \mathrm{st}$ min after anesthesia induction, at the 1st, 2nd, 3rd, 4th, 5th, and 10th min after airway insertion, and at the 3rd min after extubation. Difficulty in swallowing at postoperative was higher in Group E than in Group P. Insertion rates of the devices, were similar. Surgical satisfaction was higher in Group E than in Group P. Adequate tidal volume was provided in both groups during the operation.

Conclusion: The use of PLMA in airway management in outpatient septorhinoplasty operations creates less hemodynamic response compared to the use of ETT, less airway complications are seen and thanks to its flexibility, it does not interfere with the surgical area. PLMA may be an alternative to ETT when the insertion of the airway devices is performed by experienced physicians.

Keywords: Endotracheal intubation, laryngeal mask airway, rhinoplasty
$\ddot{\mathrm{O}} \mathrm{z}$

Amaç: Bu çalı̧̧mada amacımız elektif septorinoplasti operasyonunda ProSeal laryngeal maske havayolu (PLMA) ve endotrakeal tüp (ETT) kullanmak ve uygulama sırasında ortaya çıkan hemodinamik farklılıkları ve postoperati ve komplikasyonları karşılaştırmaktır.

Gereç ve Yöntem: Prospektif planlı çalışmada ASA I-II ve 18-35 yaş arası 60 hasta rastgele iki gruba ayrıldı $(n=30, n=30)$. Standart anestezi tekniğinin ardından Grup E'ye ETT, Grup P'ye PLMA yerleștirildi. Hastaların demografik özellikleri, doğru yerleştirme girişimleri, hemodinamik değişiklikler, ameliyat sonrası bulant1, kusma, boğaz ağrısı, ses kısıklığı, yutma güçlüğü ve cerrahi memnuniyet değerlendirildi.

Bulgular: Anestezi indüksiyonu sonrası 1. dk, havayolu yerleşimi sonrasi 1., 2., 3., 4., 5. ve 10.dk ve ekstübasyon sonrası 3.dk kalp hızı Grup E'de Grup P'ye göre daha yüksekti. Postoperatif yutma güçlüğü Grup E'de Grup P'ye göre daha yüksekti. Cihazların yerleştirme oranları benzerdi. Grup E'de Grup P'ye göre cerrahi memnuniyet daha yüksekti. Operasyon sırasında her iki grupta da yeterli tidal volüm sağlandı.

Sonuç: Günübirlik yapılan septorinoplasti operasyonlarinda havayolu yönetiminde PLMA kullanımının ETT kullanımına göre daha az hemodinamik yanıt oluşturduğunu, daha az havayolu komplikasyonu görüldüğünü ve esnekliği sayesinde cerrahi alana müdahale etmediğini saptadık. Havayolu cihazlarının yerleștirilmesi deneyimli hekimler tarafindan yapıldığında PLMA, ETT"ye alternatif olabilir.

Anahtar kelimeler: Endotrakeal entübasyon, laryngeal maske havayolu, rinoplasti

YazışmaAdresi/Address for Correspondence: Dr. DilekYeniay, Giresun University Gynecology and Chıldren Training and Research Hospital, Giresun, Turkey E-mail: dgyeniay@gmail.com

Geliștarihi/Received: 03.08.2021 Kabul tarihi/Accepted: 10.10.2021 Cevrimiçi yayın/Published online: 27.10.2021 


\section{INTRODUCTION}

Various airway devices are used to provide sufficient and safe airway with effective respiration. Among these devices, the endotracheal tube (ETT) is a subglottic airway device, whereas the ProSeal laryngeal mask airway (PLMA) is an advanced form of the classical laryngeal mask airway (KLMA) and a hypopharyngeal and supraglottic airway device. It is routinely used in general anesthesia or in cases where emergency intubation is required ${ }^{1,2}$.

Most sinus and nasal procedures are brief outpatient surgical procedures that generally do not require muscle paralysis and a smooth emergence from anesthesia is desired because coughing or bucking on awakening often stimulates venous nasal bleeding. Therefore, KLMA may be preferred in nasal and sinus surgeries ${ }^{3}$.However, the narrowing of the surgeon's working area is one of the problems in the use of laryngeal masks, and this problem disappears with the flexible and bendable feature of the PLMA4 4

Various side effects such as postoperative sore throat, dysphagia, hoarseness, edema, hyperemia, and bleeding may occur in relation to the implementation techniques, structural characteristics, size and cuff volume increases of the devices used in airway management during septorhinoplasties and duration of anesthesia. Particularly, postoperative nausea and vomiting (PNV) is a significant side effect that delays discharge and can change the case from an outpatient to an inpatient ${ }^{5,6}$.

ETT is generally preferred in septorhinoplasty surgeries. Our aim in this study is to show that the use of PLMA is safe in the surgical group and that the postoperative evaluation can be earlier and postoperative surgical complications are less than the use of ETT. There are few studies about the use of PLMA for these surgeries in the literature, and we think that this study will contribute to the literature.

Patients who were planned for septorhinoplasty with the use of PLMA or ETT in elective conditions were questioned about evaluation of the ease of insertion of both devices, their effects on hemodynamic parameters, their ability to allow positive pressure ventilation, and postoperative laryngeal disorders (nausea-vomiting, sore throat, hoarseness, difficulty in swallowing) and surgical satisfaction in this study.

\section{MATERIALS AND METHODS}

The study was approved by the institutional ethics committee (Karadeniz Technical University Faculty of Medicine Scientific Research Ethics Committee Chairman) with the number 2016/124, and informed consent was obtained from each patient.

The study was conducted in 60 patients with ASA I and II scores, aged 18-35 years with a body mass index of $<35 \mathrm{~kg} / \mathrm{m}^{2}$ who underwent elective septorhinoplasty in the plastic and reconstructive surgery operating room. Emergency patients with a full stomach, pregnant patients, those who had experienced symptoms of upper respiratory tract infection in the past two weeks, those with esophageal and pulmonary pathology, those who did not want to participate in the study were excluded (Figure 1).

\section{Randomization and anesthetic procedures}

Details such as age, height, weight, body mass index, and ASA scores of patients were evaluated and recorded preoperatively. Patients taken into the operating room were administered intravenous midazolam $0.05 \mathrm{mg} / \mathrm{kg}$ for premedication $10 \mathrm{~min}$ before surgery. Thereafter, the patients were randomly categorized into two groups after routine anesthesia monitoring [electrocardiography, noninvasive blood pressure, peripheral oxygen saturation $\left.\left(\mathrm{SpO}_{2}\right)\right]$ was performed. All anesthetic applications and follow-ups were performed by physicians, with 3-4 years of experience in anesthesia.

Anesthesia was induced intravenously (IV) with propofol (2 $\mathrm{mg} / \mathrm{kg})$, fentanyl (2 $\mu \mathrm{g} / \mathrm{kg})$, and rocuronium $(1 \mathrm{mg} / \mathrm{kg})$ for muscle relaxation. The size of the equipment was determined according to the gender and weight of the patients. The devices were checked before use and lubricated with waterbased lidocaine gel. The size of the equipment was determined according to the gender and weight of the patients. For the ETT group (Group E), 7.5-9.0 cuffed intubation tubes for adult men and 7.0-8.0 cuffs for women were used. For the PLMA group (Group P), size 4 LMA was used for patients between $50-70 \mathrm{~kg}$ and size 5 for patients with $>70 \mathrm{~kg}$. Anesthesia was maintained with 1 MAC sevoflurane in a mixture of $50 \%$ oxygen $/ 50 \%$ nitrogen protoxide $\left(\mathrm{N}_{2} \mathrm{O}\right)$. The systolic blood pressure (SBP), diastolic blood pressure (DBP), mean arterial blood pressure (MAP), heart rate (HR), and $\mathrm{SpO}_{2}$ of the patients were recorded preoperatively at the $1^{\text {st }} \mathrm{min}$ after 
induction, at 1 -min intervals in the first $5 \mathrm{~min}$ and at the $10^{\text {th }} \mathrm{min}$ after airway insertion, before extubationand at 1 -min intervals in the first $5 \mathrm{~min}$, and at the $10^{\text {th }}$ min after extubation.

The successful insertions of ETT and PLMA and after how many attempts insertion was achieved were recorded. Patients with failed PLMA insertion after the second attempt were planned to be excluded from the study. After sufficient airway was achieved, the cuffs were measured using a manometer to allow minimal air leakage and adjusted to a level of 60-70 $\mathrm{cmH}_{2} \mathrm{O}$ for PLMA and $20-30 \mathrm{cmH}_{2} \mathrm{O}$ for ETT. The variability of the pressure levels to which the cuffs were inflated were recorded at the $1^{\text {st }}, 2^{\text {nd }}, 3^{\text {rd }}, 4^{\text {th }}, 5^{\text {th }}$, and $10^{\text {th }}$ min after airway insertion and before extubation. The cuff pressure levels were continuously monitored intra operatively and reduced to normal levels using a manometer, if they exceeded the normal limits. Leakage was monitored by manual ventilation, and then mechanical ventilation was used after ventilation adjustments were made. Ventilation levels were adjusted to a tidal volume of $8 \mathrm{ml} / \mathrm{kg}$, respiratory frequency of $12 / \mathrm{min}$, positive end-expiratory pressure of $5 \mathrm{mmHg}$, inspiratory/expiratory ratio of $1 / 2$, and ventilation mode of volume-controlled ventilation. Inspiratory and expiratory tidal volumes, peak airway pressure $\left(\mathrm{P}_{\text {peak }}\right)$ and mean airway pressure $\left(\mathrm{P}_{\text {mean }}\right)$, and end-tidal carbondioxide $\left(\mathrm{ETCO}_{2}\right)$ and $\mathrm{SpO}_{2}$ levels were recorded at the $1^{\text {st }}, 2^{\text {nd }}, 3^{\text {rd }}, 4^{\text {th }}, 5^{\text {th }}$, and $10^{\text {th }}$ min after airway insertion and before extubation. Ppeak $<20$ $\mathrm{cmH}_{2} \mathrm{O}$, absence of leak sound, and symmetrical chest participation in respiration were taken as criteria for a clinically correct PLMA. If the surgical area was sufficient for the surgeon, the procedure was continued. Depth of anesthesia was evaluated by conventional methods such as ventilation, pupil diameter, tears, sweating, heart rate, and blood pressure.

Prior to extubation, IV tramadol $1.5 \mathrm{mg} / \mathrm{kg}$ was administered as a postoperative analgesic and IV ondansetron 2-4 mg was administered to prevent opioid-induced nausea and vomiting. At the end of the operation, the ETT or PLMA was removed after the patients' protective reflexes returned and their spontaneous respiration was sufficient. Subsequently, all patients were IV administered sugammadex 2 $\mathrm{mg} / \mathrm{kg}$ for residual block and transferred to the postoperative care unit.

\section{Measures}

The patients were evaluated for the complaints of sore throat, hoarseness, dysphagia, and PNV at the postoperative $10^{\text {th }} \mathrm{min}$ and $2^{\text {nd }}, 8^{\text {th }}$, and $24^{\text {th }} \mathrm{h}$. The Numeric Rating Scale (NRS) was used to evaluate the level of soreness ofthe throat ${ }^{7}$. Patients who received an NRS score of $>4$ points in the recovery room were classified as those with severe pain and administered IV meperidine $0.5 \mathrm{mg} / \mathrm{kg}$ as an additional analgesic. Patients without pain and those with an NRS score of $\leq 4$ who were in the category of mild pain were referred to the plastic surgery unit with an Aldrete score of 8-10. All patients were discharged before the $24^{\text {th }}$.

Pain assessment at the $24^{\text {th }} \mathrm{h}$ was performed by talking to the patient on phone. A two-point scoring system was used for assessing dysphagia, level of hoarseness, and PNV (0, none; 1, yes $)^{8,9}$. The satisfaction of the surgeon performing the procedure was evaluated using a four-point scoring system postoperatively. (0, Very good; 1, Good; 2, Bad; 3, Very bad; to the point where surgery cannot be performed).

\section{Statistical analysis}

The sample size was based on the study of Jarineshin et al. Heart rate value before placing the device in ETT group is $86 \pm 16 / \mathrm{min}$. Considering that it would be 10 beats / min different from this value in the PLMA group, it was calculated by the $G *$ Power program that 30 patients should be taken in each group at $80 \%$ power and $95 \%$ confidence level ${ }^{10}$. A total of 60 patients $(30+30)$ were included in the study. The SPSS 22.0 statistical package software was used to analyze the data.

Categorical variables was expressed in number and percentage in descriptive statistics, whereas mean and standard deviation were used to express continuous variables. The normality of distribution for continuous variables was confirmed with the Shapiro Wilk test. Chi-square test was used to compare categorical variables between the groups. For comparison of continuous variables between two groups, the Student's t-test or Mann-Whitney U test was used depending on whether the statistical hypotheses were fulfilled or not. The statistical level of significance for all tests was considered to be 0.05 . 


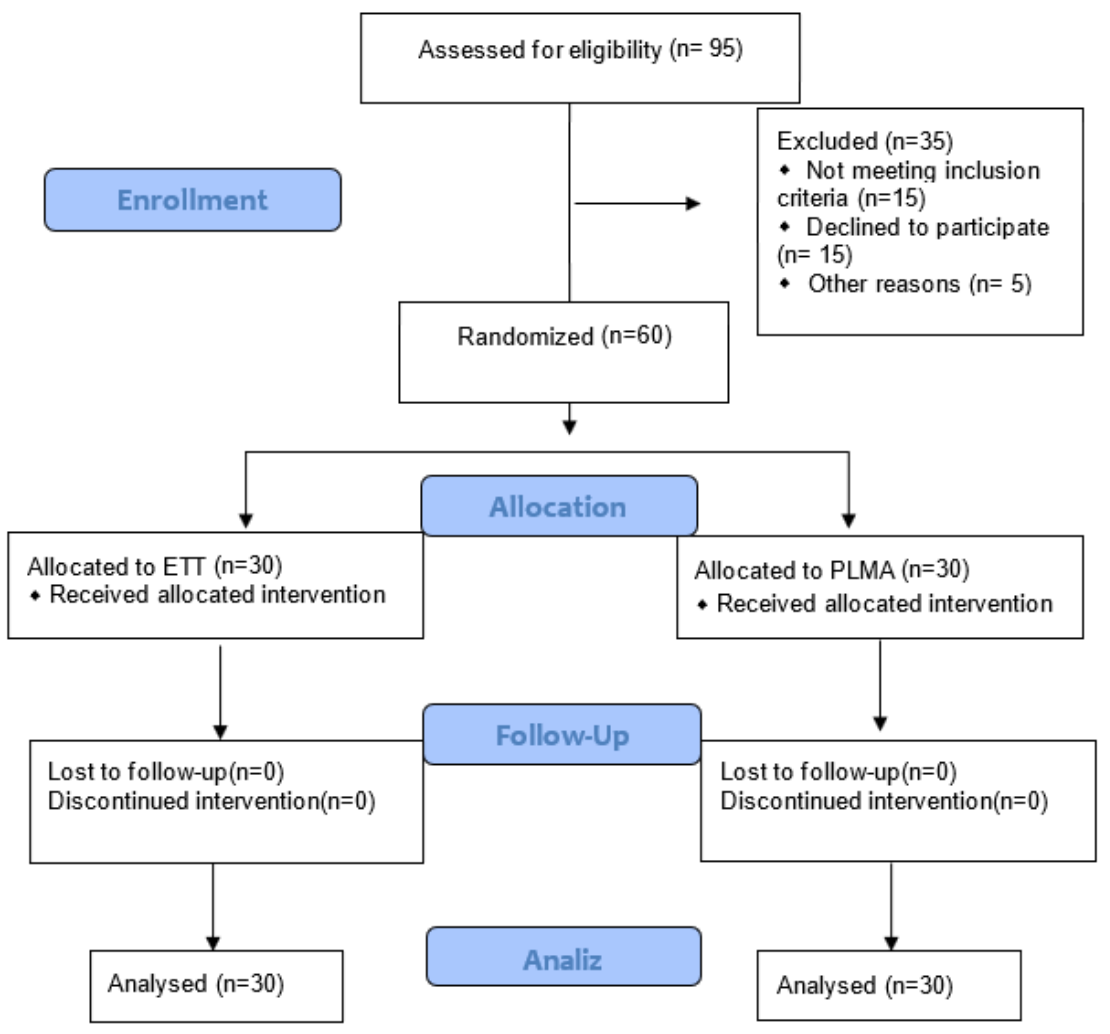

Figure 1. Consolidated Standards of Reporting Trials diagram showingt he flow of participants (study enrollment, randomization, andprocedures).

Table 1. Patients' demographic characteristics

\begin{tabular}{|l|c|c|c|c|c|c|c|}
\hline & \multicolumn{3}{|c|}{ GRUP E } & \multicolumn{3}{c|}{ GRUP P } & \\
\hline & \multicolumn{3}{|c|}{ Mean \pm SD } & \multicolumn{3}{c|}{ Mean \pm SD } & $p$ \\
\hline Age (years) & 26.67 & \pm & 7.17 & 25.20 & \pm & 7.78 & 0.39 \\
\hline Height $(\mathrm{cm})$ & 168.20 & \pm & 9.49 & 167.30 & \pm & 6.98 & 0.67 \\
\hline Weight $(\mathrm{kg})$ & 64.50 & \pm & 13.91 & 65.17 & \pm & 10.95 & 0.83 \\
\hline Body mass index (kg m-2) & 22.60 & \pm & 3.20 & 23.18 & \pm & 2.82 & 0.453 \\
\hline Operation time(min) & 78.00 & \pm & 3.85 & 79.00 & \pm & 3.57 & 0.301 \\
\hline
\end{tabular}

Values are the mean $\pm \mathrm{SD}, p<0.05$ significant value

\section{RESULTS}

Demographic data were similar between the two groups included in the study ( $>>0.05$; Table1). Among the hemodynamic parameters of patients recorded at certain intervals throughout the duration of surgery, HR was significantly lower in Group P than in Group E at the $1^{\mathrm{st}} \mathrm{min}$ after the induction of anesthesia, at the $1^{\text {st }}, 2^{\text {nd }}, 3^{\text {td }}, 4^{\text {th }}, 5^{\text {th }}$, and $10^{\text {th }}$ min after airway insertion, and at the $3^{\text {rd }}$ min after extubation $(\mathrm{p}<0.05)$. However, it was not clinically significant. SBP values were higher in Group $E$ than in Group $P$ at the $1^{\text {stmin }}$ after airway insertion $(p=0.048)$. DBP values were higher in Group $E$ than in Group $\mathrm{P}$ at the $2^{\text {nd }}$ min after airway insertion $(p=0.013)$. At the other times, SBP and DBP values were similar between the groups ( $p>0.05$; Graphic 12 ). Because the insertion of the devices was performed by experienced physicians, no significant difference was observed between the groups in terms 
of the ease of insertion ( $p>0.05$; Table 2). The results were similar when the groups were compared in terms of the MAP, $\mathrm{SPO}_{2}(\mathrm{p}>0.05)$. The groups were similar when compared in terms of airway peak pressure and airway mean pressure $(\mathrm{p}>0.05$; Table 3). Adequate tidal volume was provided in both groups during the operation. Because the normal range cuff pressure levels of the groups were independent of each other, both the groups were compared among themselves. In both groups, the cuff pressure levels at the $3^{\text {td }}, 4^{\text {th }}, 5^{\text {th }}$, and $10^{\text {th }} \mathrm{min}$ after airway insertion and before extubation were significantly higher than those when the mask was first inflated $(p<0.05)$. In Group E, the number of patients with NRS $>4$ for sore throat in all follow-up periods was higher than Group P, so analgesic consumption was higher, but it was not statistically significant ( $p>0.05$; Table $4 a$ ).

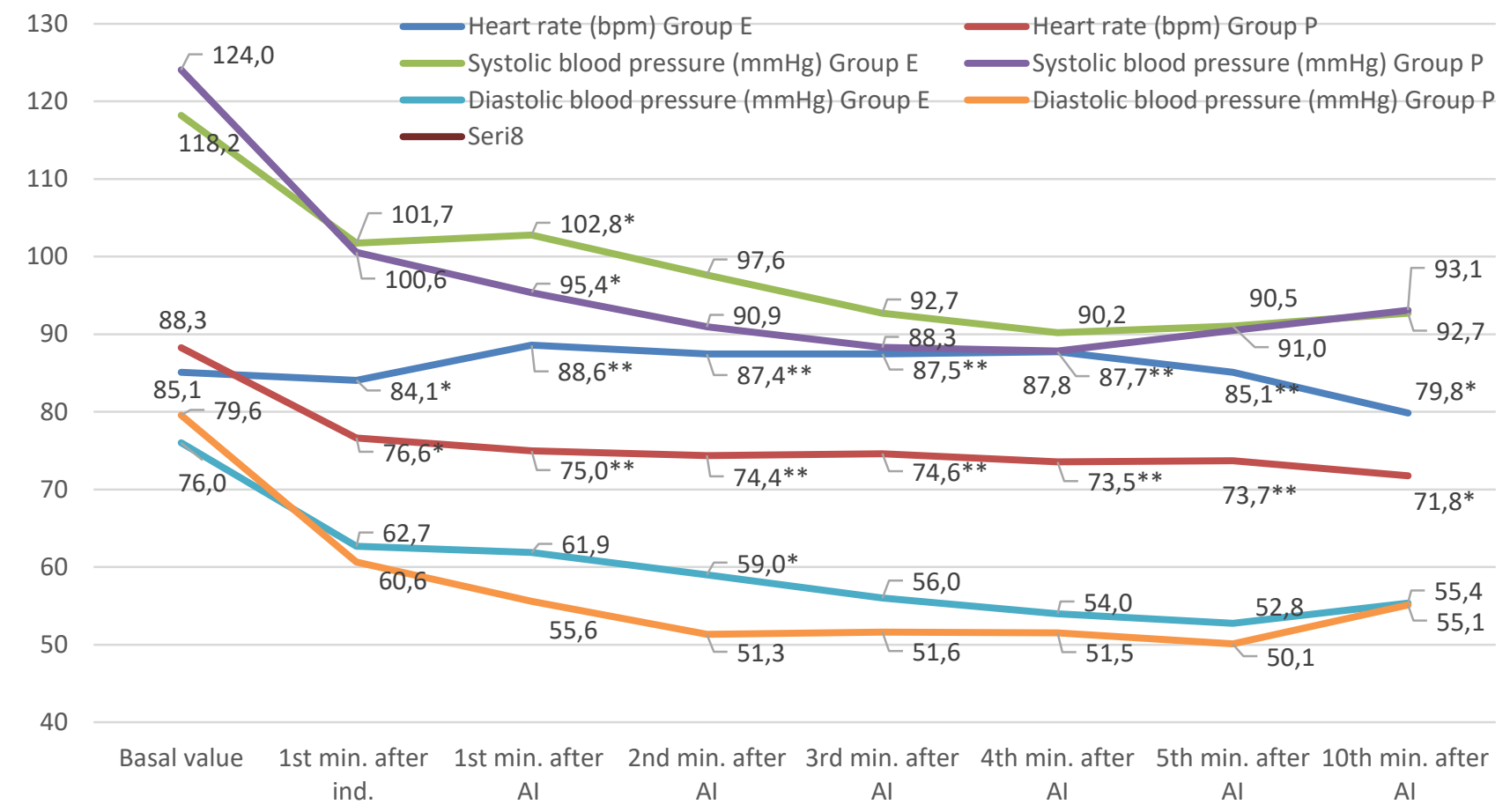

*: $\mathrm{p}<0.05,{ }^{* *}: \mathrm{p}<0.01$ significant value Ind.: Induction, AI: Airway Insertion

Graphic 1. Comparison of hemodynamic parameters of the groups (basal and after airway insertion)

Table 2. Number of attempts at insertion

\begin{tabular}{|c|c|c|c|}
\hline \multirow[t]{2}{*}{ Insertion rate } & GRUP E & GRUP P & \multirow[t]{2}{*}{$\mathrm{p}$} \\
\hline & $\mathrm{n}(\%)$ & $\mathrm{n}(\%)$ & \\
\hline Success at the first attempt without resistance & $26(\% 86.7)$ & $27(\% 90)$ & \multirow[t]{4}{*}{0,688} \\
\hline Success at the first attempt with resistance & $4(\% 13.3)$ & $3(\% 10)$ & \\
\hline Success at the second attempt & $0(\% 0)$ & $0(\% 0)$ & \\
\hline Failure at the second attempt & $0(\% 0)$ & $0(\% 0)$ & \\
\hline
\end{tabular}

$p<0.05$ significant value 


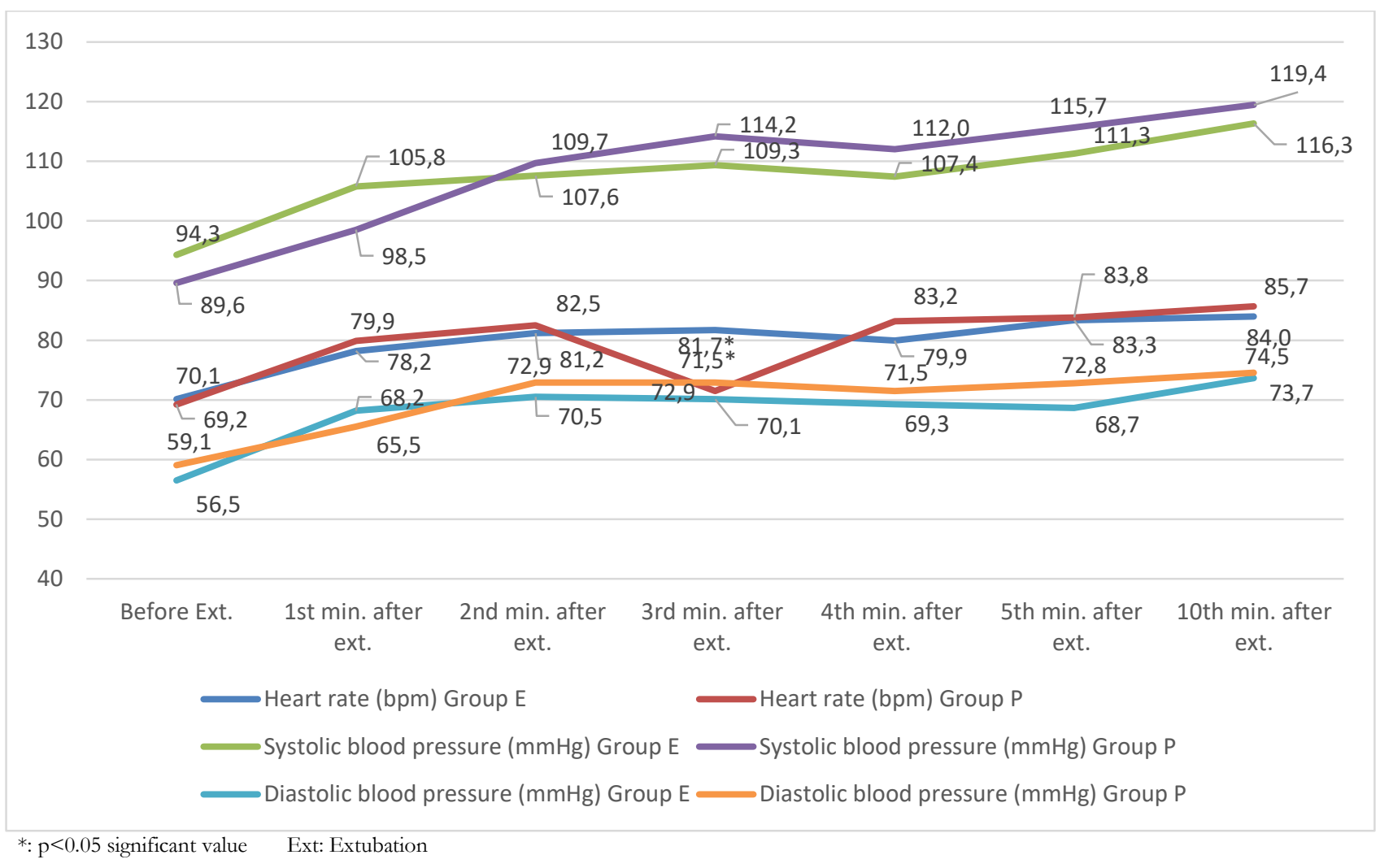

Graphic 2. Comparison of hemodynamic parameters of the groups (before and after extubation)

Table 3. Ppeak and Pmean values of the groups (Ort \pm SD)

\begin{tabular}{|l|c|c|c|c|c|c|c|}
\hline & \multicolumn{3}{|c|}{ GRUP E } & \multicolumn{3}{c|}{ GRUP P } & \multirow{2}{*}{ p } \\
\cline { 1 - 6 } & \multicolumn{3}{|c|}{ Ort \pm SD } & \multicolumn{3}{c|}{ Ort \pm SD } & \\
\hline 1st min after AI Ppeak & 14.37 & \pm & 2.092 & 14.4 & \pm & 2.762 & 0.940 \\
\hline 2st min after AI Ppeak & 14.57 & \pm & 2.431 & 13.9 & \pm & 3.021 & 0.982 \\
\hline 3st min after AI Ppeak & 14.4 & \pm & 2.238 & 13.7 & \pm & 3.007 & 0.845 \\
\hline 4st min after AI Ppeak & 14.27 & \pm & 1.893 & 14.23 & \pm & 2.096 & 1.000 \\
\hline 5st min after AI Ppeak & 14.2 & \pm & 3.123 & 13.63 & \pm & 3.368 & 0.940 \\
\hline 10st min after AI Ppeak & 14.83 & \pm & 2.036 & 14.5 & \pm & 1.907 & 0.940 \\
\hline Before Ext.Ppeak & 14.57 & \pm & 3.126 & 15.17 & \pm & 2.506 & 0.415 \\
\hline 1st min after ExtPmean & 5.77 & \pm & 1.135 & 5.5 & \pm & 1.432 & 0.517 \\
\hline 2st min after ExtPmean & 5.93 & \pm & 1.388 & 5.23 & \pm & 1.331 & 0.051 \\
\hline 3st min after ExtPmean & 5.83 & \pm & 1.367 & 5.2 & \pm & 1.349 & 0.090 \\
\hline 4st min after ExtPmean & 5.73 & \pm & 1.363 & 5.37 & \pm & 1.217 & 0.130 \\
\hline 5st min after ExtPmean & 5.8 & \pm & 1.4 & 5.3 & \pm & 1.236 & 0.060 \\
\hline 10st min after ExtPmean & 6.03 & \pm & 1.299 & 5.27 & \pm & 1.437 & 0.055 \\
\hline Before ExtPmean & 6.2 & \pm & 1.095 & 5.67 & \pm & 1.583 & 0.533 \\
\hline
\end{tabular}

$p<0.05$ significant value. Ind.: Induction, AI: Airway Insertion, Ext: Extubation 
,Table 4a. Comparison of postoperative complications

\begin{tabular}{|c|c|c|c|c|}
\hline & \multicolumn{3}{|c|}{ Postoperative Sore Throat } \\
\hline & & Group E & Group P & \\
\hline & & n (\%) & $\mathrm{n}(\%)$ & $p$ \\
\hline \multirow[t]{3}{*}{ 10th min } & Absent & $21(\% 70)$ & $27(\% 90)$ & \multirow[t]{3}{*}{0.145} \\
\hline & Mild & $2(\% 6.7)$ & $1(\% 3.3)$ & \\
\hline & Severe & $7(\% 23.3)$ & $2(\% 6.7)$ & \\
\hline \multirow[t]{3}{*}{ 2nd h } & Absent & $23(\% 76.7)$ & $28(\% 93.3)$ & \multirow[t]{3}{*}{0.175} \\
\hline & Mild & $1(\% 3.3)$ & $2(\% 6.7)$ & \\
\hline & Severe & $6(\% 20)$ & & \\
\hline \multirow[t]{3}{*}{ 8th $\mathrm{h}$} & Absent & $26(\% 86.7)$ & $29(\% 96.7)$ & \multirow[t]{3}{*}{0.287} \\
\hline & Mild & $2(\% 6.7)$ & $1(\% 3.3)$ & \\
\hline & Severe & $2(\% 6.7)$ & & \\
\hline \multirow[t]{3}{*}{ 24th h } & Absent & $28(\% 93.3)$ & $28(\% 93.3)$ & \multirow[t]{3}{*}{0.513} \\
\hline & Mild & $1(\% 3.3)$ & $2(\% 6.7)$ & \\
\hline & Severe & $1 \% 3.3)$ & & \\
\hline
\end{tabular}

$p<0.05$ significant value

Table 4b. Comparison of postoperative complications

\begin{tabular}{|c|c|c|c|c|c|c|c|c|c|c|c|}
\hline & & \multicolumn{4}{|c|}{ Postoperative Nausea and Vomiting } & & \multicolumn{4}{|c|}{ Postoperative Swallowing Difficulty } & \\
\hline & & $\begin{array}{c}\text { Group } \\
E\end{array}$ & Group P & & \multirow[t]{2}{*}{$\begin{array}{l}\text { Odds } \\
\text { Ratio }\end{array}$} & & Group E & Group P & & \multirow[t]{2}{*}{$\begin{array}{l}\text { Odds } \\
\text { Ratio }\end{array}$} & \\
\hline & & n (\%) & n (\%) & $\mathrm{p}$ & & $\begin{array}{c}95 \% \\
\text { CI } \\
\end{array}$ & n (\%) & n (\%) & $\mathrm{p}$ & & $\begin{array}{l}95 \% \\
\text { CI } \\
\end{array}$ \\
\hline \multirow[t]{2}{*}{$\begin{array}{l}10^{\text {th }} \\
\min \end{array}$} & No & $\begin{array}{c}27 \\
(90)\end{array}$ & $28(93.3)$ & \multirow[t]{2}{*}{0.640} & 1.556 & $\begin{array}{l}0.240- \\
10049\end{array}$ & $19(63.3)$ & $26(86.7)$ & \multirow[t]{2}{*}{$0.037 *$} & \multirow[t]{2}{*}{3.763} & $\begin{array}{c}1.037- \\
13.646\end{array}$ \\
\hline & Yes & $3(10)$ & $2(6.7)$ & & & & $11(36.7)$ & $4(13.3)$ & & & \\
\hline \multirow[t]{2}{*}{$\begin{array}{l}2^{\text {nd }} \\
h\end{array}$} & No & $\begin{array}{c}26 \\
(86.7)\end{array}$ & $27(90)$ & \multirow[t]{2}{*}{0.680} & 1.384 & $\begin{array}{c}0.282- \\
6.759\end{array}$ & $19(63.3)$ & $27(90)$ & \multirow[t]{2}{*}{$0.015^{*}$} & 5.210 & $\begin{array}{c}1.278- \\
21.237\end{array}$ \\
\hline & Yes & $\begin{array}{c}4 \\
(13.3) \\
\end{array}$ & $3(10)$ & & & & $11(36.7)$ & $3(10)$ & & & \\
\hline \multirow[t]{2}{*}{$\begin{array}{l}8^{\text {th }} \\
\text { h }\end{array}$} & No & $\begin{array}{c}27 \\
(90) \\
\end{array}$ & $30(100)$ & \multirow[t]{2}{*}{0.076} & 7.763 & $\begin{array}{l}0.383- \\
157.14 \\
\end{array}$ & $25(83.3)$ & $28(93.3)$ & \multirow[t]{2}{*}{0.228} & 2.800 & $\begin{array}{c}0.498- \\
15.734 \\
\end{array}$ \\
\hline & Yes & $3(10)$ & 0 & & & & $5(16.7)$ & $2(6.7)$ & & & \\
\hline \multirow[t]{2}{*}{$\begin{array}{l}24^{\text {th }} \\
h^{-1}\end{array}$} & No & $\begin{array}{c}29 \\
(96.7)\end{array}$ & $30(100)$ & \multirow[t]{2}{*}{0.310} & 3.101 & $\begin{array}{l}0.121- \\
79.232\end{array}$ & $28(93.3)$ & $30(100)$ & \multirow[t]{2}{*}{0.150} & 5.350 & $\begin{array}{c}0.246- \\
116.316\end{array}$ \\
\hline & Yes & $1(3.3)$ & 0 & & & & $2(6.7)$ & 0 & & & \\
\hline
\end{tabular}

${ }^{*} \mathrm{p}<0.05$ significant value, CI: Confidence interval.

Table 5. Evaluation of surgical satisfaction by groups

\begin{tabular}{|l|c|c|c|}
\hline Surgical satisfaction & $\begin{array}{c}\text { Group E } \\
\text { n (\%) }\end{array}$ & $\begin{array}{c}\text { Group P } \\
\text { n (\%) }\end{array}$ & p \\
\hline Very good & $30(100 \%)$ & $9(30 \%)$ & \\
\cline { 1 - 3 } Good & $0(0 \%)$ & $17(56.7)$ & \multirow{2}{*}{$0.001 *$} \\
\hline Bad & $0(0 \%)$ & $4(13.3 \%)$ & \\
\hline $\begin{array}{l}\text { Very bad (to the point where surgery cannot be } \\
\text { performed) }\end{array}$ & $0(0 \%)$ & $0(0 \%)$ & \\
\hline
\end{tabular}

${ }^{*} p<0.05$ significant value

Although nausea-vomiting and sore throat rates were higher in Group E during all postoperative follow-up periods, these rates were not significant $(\mathrm{p}>0.05)$. When the groups were compared in terms of difficulty in swallowing, there was significantly greater swallowing difficulty in Group $\mathrm{E}$ than in Group $\mathrm{P}$ at the postoperative $10^{\text {th }} \mathrm{min}$ and $2^{\text {ndh }}$ $(\mathrm{p}<0.05)$. No significant difference was observed 
between the groups at the $8^{\text {th }}$ and $24^{\text {th }}$ h $(p>0.05$; Table 4b). Although analgesic consumption was higher in all follow-up periods in Group E, it was not statistically significant $(\mathrm{p}>0.05)$. No hoarseness was observed in either group. Surgical satisfaction was evaluated as very good in 100\% of patients in Group $\mathrm{E}$, but very good results were obtained in only nine patients (30\%) in Group P; this difference was statistically significant ( $p=0.00$; Table 5$)$.

\section{DISCUSSION}

Today, septorhinoplasty is the most common surgical procedure in plastic and reconstructive surgery ${ }^{11}$. Among the main problems, we focus on achieving rapid recovery of these patients from anesthesia and achieving early discharge by reducing the incidence of PNV and sore throat, which are very common postoperatively. After comparing the uses of PLMA and ETT for airway management during septorhinoplasty, we have found that Group P had less hemodynamic changes and airway complications. In addition, air leaks did not make ventilation difficult, and PLMA was not an obstacle for performing the procedure at the surgical area because of its flexibility. At the same time, we found that with the use of PLMA, airway leaks do not complicate ventilation and that the targeted tidal volume can be maintained throughout the case.

The ETT is the most reliable airway device in protecting the airway from aspiration, providing a completely open airway and achieving ventilation during septorhinoplasty. However, the occurrence of severe hemodynamic changes during laryngoscopy and the use of muscle relaxant drugs that prevent rapid recovery in short-staypatients have led to the development of alternative airway devices to ETT. Supraglottic airway devices, particularly the KLMA and its variants, have become reliable alternatives to ETT for performing controlled ventilation ${ }^{12}$. PLMA provides good ventilation by preventing air leakage at high pressures thanks to its cuff. With this feature, it provides significant superiority to the KLMA ${ }^{13}$.

All other supraglottic airway devices like PLMA have less effect on hemodynamic parameters because they cause less sympathetic stimulation during intubation and extubation compared to endotracheal airway devices ${ }^{14}$. Kannan et al. in their study comprising 60 cases compared ETT and PLMA in terms of respiratory efficacy and airway dynamics and found that the PLMA group had a significantly lower HR at the $1^{\text {stmin }}$ after airway insertion $(p=0.048)^{15}$. SBP, $\mathrm{DBP}$, and MAP were also significantly lower in the PLMA group at the $1^{\text {st }}$ and $2^{\text {nd }}$ min after airway insertion $(p<0.05)$. In the present study, HR was significantly higher at the $1^{\text {st }}, 2^{\text {nd }}, 3^{\text {rd }}, 4^{\text {th }}, 5^{\text {th }}$, and $10^{\text {th }}$ min after airway insertion and at the $3^{\text {rd }}$ min after extubation in Group E than in Group P. SBP was significantly higher at the $1^{\text {st }}$ min after airway insertion and DBP was significantly higher at the $2^{\text {nd }}$ min after airway insertion in Group $\mathrm{E}$ than in Group P. MAP levels were similar between the groups. This might be due to the intubation tube causing more sympathetic stimulation or PLMA causing minimal stimulation of respiratory and cardiac reflexes.

Hohlrieder et al. studied 200 patients and found that the rate of insertion at the first attempt was $99 \%$ for PLMA and $97 \%$ for ETT ${ }^{16}$. They suggested that this success rate for PLMA was dependent on the use of a guide and PLMA used without a guide would be more difficult to insert and might cause more mucosal damage. In the present study, the success rate at the first attempt without resistance was $90 \%$ in the PLMA group and $86.7 \%$ in the ETT group, and no significant difference was observed. Insertion was achieved at the first attempt in three patients in the PLMA group and in four in the ET'T group with resistance, thus a second attempt was not required. In our opinion, the reason for this success is that the anesthetists using the devices are experienced physicians. In addition, in this success, we believe that PLMA does not have a rear cuff and the curl formed when the cuff is deflated facilitates the insertion.

Incorrect placement of the LMA tip between the false cords puts pressure on the vocal cords and can therefore lead to trauma and possible paresis ${ }^{17}$. Traditionally, if the LMA is placed correctly; 1) clinical assessments; Resistance during LMA placement, ventral displacement of the LMA after the cuff is inflated, symmetrical chest movements, 2) ventilation-related parameters; ETCO2 value, airway pressures; volume change in the reservoir balloon, 3) Can be determined by fiberoptic bronchoscopy ${ }^{18-}$ ${ }^{19}$.In our study, it was thought that the PLMA was placed correctly, Ppeak was $<20 \mathrm{cmH} 2 \mathrm{O}$ and the chest was symmetrically participating in respiration.Hoarseness was not observed in any patient in either group, both for this reason and because we measured the cuff pressures with a manometer at certain intervals of the operation and reduced it to normal values if it exceeded the recommended values $\left(60 \mathrm{cmH}_{2} \mathrm{O}\right.$ for PLMA, 20-30 
$\mathrm{cmH}_{2} \mathrm{O}$ for ETT). Other complications that can be seen due to LMA; Morbidities such as aspiration of gastric contents, mucosal destruction, throat dryness and burning sensation, dysphonia, dysphagia, loss of taste sensation, narrowing of the carotid diameter due to cuff pressure are of concern to the anesthesiologist. Although there were no significant results in many studies in which ETT and PLMA were compared in terms of complications such as postoperative nausea-vomiting, sore throat, hoarseness, and difficulty in swallowing and cough, complications have occurred in more patients in the ETT group than in the PLMA group ${ }^{15-16,20-23)}$. In the present study, no significant difference was observed at any time point between the groups in terms of nausea, vomiting, sore throat, and hoarseness. However, more patients in the ETT grouphad nausea and sore throat at all time points than in the PLMA group; therefore, more patients in the ETT group needed analgesics. PLMA is a double-lumen doublecuff laryngeal mask airway.

When the groups were compared in terms of difficulty in swallowing, the ETT group had significantly greater difficulty than the PLMA group at postoperative $10^{\text {th }} \mathrm{min}$ and $2^{\text {nd }}$ h. No significant difference was observed between the groups at the $8^{\text {th }}$ and $24^{\text {th }} \mathrm{h}$. According to the results of the present study, a cuff in the pharynx might be less stimulating than a cuff in the trachea. Our inability to measure hoarseness using a device that measures patients' sound frequency is the secondary limitation of the study.

Undesirable complications may occur in the upper airway due to anatomical differences in patients undergoing airway device insertion ${ }^{24}$. Because of its flexibility, PLMA can be easily used in nasal surgeries, where the size of the oral cavity or surgical areais important. In addition, because the aesthetic concerns are greater in septorhinoplasty, it is important for the surgeon to have alarge and comfortable surgical area. In the present study, surgical satisfaction was evaluated as very good in $100 \%$ patients in the ETT group, whereas it was very good, good, and bad in 30\%, 56.7\%, and $13.3 \%$ patients, respectively, in the PLMA group. The reason for bad evaluation was the occurrence of gas leakage. There was no problem regarding the surgical area because of the flexibility of the PLMA.

The limitation of our study is that the fiberoptic device (FOB), which is accepted as the gold standard for determining the location of the LMA, and the
Bispectral Index (BIS) device, which is used to determine the depth of anesthesia, are not available in our hospital. Another limitation of our study is that we cannot measure hoarseness by using a device that measures vocal frequency in individuals.

In conclusion, rapid recovery from anesthesia and early discharge is important in short-stay patients undergoing septorhinoplasty. In the present study, we found that PLMA caused a better hemodynamic profile during surgery compared to ETT, and less frequent swallowing difficulties after surgery. In addition, we have seen that ProSeal laryngeal mask does not interfere with the operation in the surgical field thanks to its unique double-tube design and flexibility. PLMA may be an alternative to ETT when the insertion of the airway devices is performed by experienced physicians.

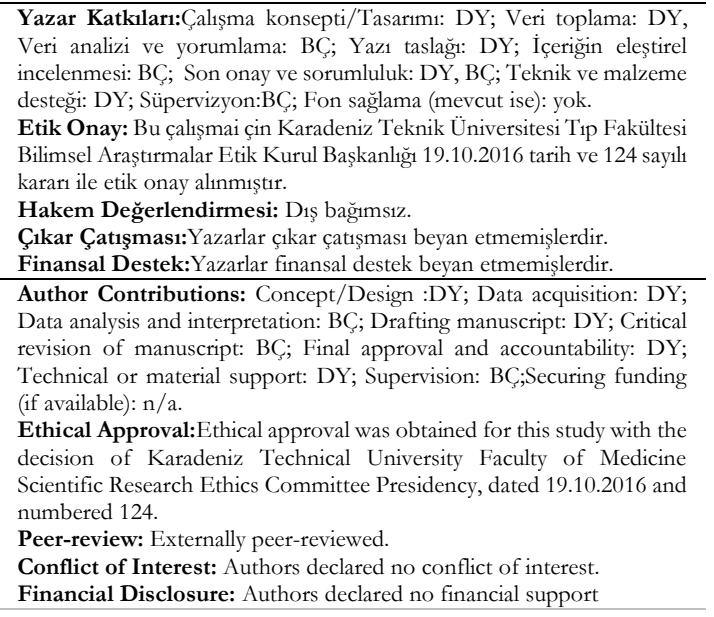

\section{REFERENCES}

1. Cook TM, Lee G, Nolan JP. The ProSeal laryngeal mask airway: a review of the literature. Can J Anesth. 2005;52:739-60.

2. Natalini G, Lanza G, Rosano A, Dell'Agnolo P, Bernardini A. Standard laryngeal mask airway and LMA-ProSeal during laparoscopic surgery. J Clin Anesth. 2003;15:428-32.

3. Kaplan A, Crosby GJ, Bhattacharyya N. Airway protection and the laryngeal mask airway in sinus and nasal surgery. Laryngoscope. 2004;114:652-5.

4. Wheeler M. Proseal laryngeal mask airway in 120 pediatric surgical patients: a prospective evaluation of characteristics and performance. Paediatr Anaesth. 2006;16:297-301.

5. Cukurova I, Cetinkaya EA, Mercan GC, Demirhan E, Gumussoy M. Retrospective analysis of 697 septoplasty surgery cases: packing versus trans-septal 
suturing method. Acta Otorhinolaryngol Ital. 2012;32:111-4.

6. Karbasforushan A, Hemmatpoor B, Makhsosi BR, Mahvar T, Golfam P, Khiabani B. The effect of pharyngeal packing during nasal surgery on the incidence of postoperative nausea, vomiting, and sore throat. Iran J Otorhinolaryngol. 2014;26:219-23.

7. Tulunay M, Tulunay FC. Assessment of pain and measurements of pain. In: Erdine S. (ed). Pain. 1. Edition. Istanbul, Nobel bookstore; 2000: 91-110.

8. Tural K, Süslü H, Arslan G, Özyurt Y. Kısa süreli ameliyatlarda laringeal maske havayolu ve cobra perilaringeal havayolunun etkinlik ve komplikasyonlarının karşılaştırılması. Kartal Eğitim ve Araştırma Hastanesi Tip Dergisi. 2009;20(2):57-65

9. Doksrod S, Lofgren B, Nordhammer A, Svendsen MV, Gisselsson L, Raeder J. Reinforced laryngeal mask airway compared with endotracheal tube for adenotonsillectomies. Eur J Anaesthesiol. 2010;27:941-6.

10. Jarineshin H, Kashani S, Vatankhah M, AbdulahzadeBaghaee A, Sattari S, Fekrat F. Better hemodynamic profile of laryngeal mask airway insertion compared to laryngoscopy and tracheal intubation. Iran Red Crescent Med J. 2015;17:e28615.

11. DurmuşKocaaslan FN, Bayramiçli M. Patient analysis and planning in aesthetic rhinoplasty. Vargel $\dot{\mathrm{I}}$, (editor). Nasoplasty in Every Aspect. 1st Edition. Ankara: Turkey Clinics. 2019;7-12.

12. Aziz L. Bashir K. Comparison of armoured laryngeal mask airway with endotracheal tube for adenotonsillectomy. J Coll Physicians Surg Pak. 2006;16:685-8.

13. Güngör $G$, Bozkurt PS, Yüceyar L. Comparison of classic and ProSeal laryngeal mask airways (LMA) in pediatric patients. Izmir Dr.Behçet Uz Children's Hospital Journal. 2016;6:46-52.

14. Garg R, Verma S. Cobra perilaryngeal airway for thyroid surgery in a hypertensive patient. J Anesth. 2009;23:469-70.

15. Kannan S, Harsoor SS, Sowmiya L, Nethra SS, DevikaRani D, Sathesha M. Comparison of ventilatory efficacy and airway dynamics between ProSeal laryngeal mask airway and endotracheal tube in adult patients during general anesthesia. J Anaesthesiol Clin Pharmacol. 2015;31:517-21.

16. Hohlrieder M, Brimacombe J, von Goedecke A, Keller C. Postoperative nausea, vomiting, airway morbidity, and analgesic requirements are lower for the ProSeal laryngeal mask airway than the tracheal tube in females undergoing breast and gynaecological surgery. Br J Anaesth. 2007;99:576-80.

17. Lloyd Jones FR, Hegab A. Case report. Recurrent laryngeal nerve palsy after laryngeal mask airway insertion. Anaesthesia. 1996;51:171-2.

18. Ghai B, Ram J, Makkar JK, Wig J. Fiber-optic assessment of LMA position in children: a randomized crossover comparison of two techniques. Paediatr Anaesth. 2011;21:1142-7.

19. Sanders JC, Olomu PN, Furman JR. Detection, frequency and prediction of problems in the use of the proseal laryngeal mask airway in children. Paediatr Anaesth. 2008;18:1183-9.

20. Ovat E, Örkei TK, Güzelmeriç F, Gürcü E, Koçak T. Effects of endotracheal intubation or proseal laryngeal mask application on hemodynamics, ventilation and gastric distension in laparoscopic cholecystectomy. Anestezi Dergisi. 2012;20:99-102.

21. Leena G, Sambhram S, Shivam G. A prospective, randomized comparative study for use of proseal laryngeal mask airway as an alternative to endotracheal intubation for airway management in children under general anesthesia. Indian J Clin Anaesth. 2016;3:804.

22. Tekin M, Kati I, Tomak Y, Yuca K. Comparison of the effects of room air and $\mathrm{N} 2 \mathrm{O}+\mathrm{O} 2$ used for ProSeal LMA cuff inflation on cuff pressure and oropharyngeal structure. J Anesth. 2008;22:467-70,

23. Hohlrieder M, Brimacombe J, Eschertzhuber S, Ulmer H, Keller C. A study of airway management using the ProSeal LMA laryngeal mask airway compared with the tracheal tube on postoperative analgesia requirements following gynaecological laparoscopic surgery. Anaesthesia. 2007;62:913-8.

24. McHardy FE, Chung F. Postoperative sore throat: cause, prevention and treatment. Anaesthesia. 1999;54:444-53. 